\title{
EKSISTENSI DAN IMPLIKASI RECAAP TERHADAP PENGUATAN KEAMANAN MARITIM DI KAWASAN ASIA TENGGARA
}

\author{
Muhammad Alif Andyva \\ Departemen Hubungan Internasional Universitas Hasanuddin \\ (malifandyva@gmail.com) \\ Agussalim Burhanuddin \\ Departemen Hubungan Internasional Universitas Hasanuddin \\ (agussalim.fisip@unhas.ac.id)
}

\begin{abstract}
Abstrak
ReCAAP didirikan dengan tujuan untuk melawan pembajakan dan perampokan bersenjata mempengaruhi situasi keamanan maritime Asia Tenggara. Dalam hal ini, ReCAAP membantu memberikan informasi yang diperlukan, memperkuat koordinasi di antara titik-tik utama (focal points), dan memperkuat kemampuan anggota untuk beradaptasi dengan tren perampokan dan perampokan bersenjata. Namun, ada hambatan dalam ReCAAP untuk memastikan keamanan maritim, termasuk pada kemampuan penegakan hukum dan kemampuan hukum terhadap individu yang dicurigai. Di sisi lain, implikasi ReCAAP mempengaruhi secara politis, dalam hal hubungan antar negara di kawasan ini, dan secara strategis, untuk memperkuat keamanan maritim. Dengan demikian, situasi tersebut menyebabkan kondisi semakin kompleks untuk mencapai kestabilan, terutama bila ada kemungkinan untuk menghambat hubungan baik antar negara tetangga di wilayahnya
\end{abstract}

Kata kunci: Regional Cooperation Agreement on Combating Piracy and Armed Robbery Against Ships in Asia, ReCAAP, Pembajakan, Maritime Security, Asia Tenggara.

\begin{abstract}
ReCAAP was founded with an aim to fight against sea-piracy and armed robbery that affected Southeast Asia maritime security. In doing so, ReCAAP helped by providing important information, increasing coordination between focal points, and enhancing the members' ability to adapt with piracy and armed robbery at sea. However, there were challenges for ReCAAP to ensure the maritime security, including law enforcement ability and measurement on suspected individuals. On the other hand, ReCAAP had political influences in terms of states relationship in the region, and strategically, empowering maritime security. This led to a more complex situation in order to achieve stability, particularly when there was a possible hinder of good relationship between neighboring states in the region.
\end{abstract}

Keywords: Regional Cooperation Agreement on Combating Piracy and Armed Robbery Against Ships in Asia, ReCAAP, Sea-piracy, Maritime Security, Southeast Asia. 


\section{Pendahuluan}

Perkembangan dunia global saat ini tidak luput dari isu - isu kontemporer yang terus bermunculan dikarenakan perubahan tren serta waktu yang terus mendorong perubahan pada kepentingan negara maupun non - negara dalam menghadapi hal - hal yang terjadi di kawasannya maupun di lingkungan tetangganya. Kondisi ini tidak luput pada kawasan Asia Tenggara, yang memegang beberapa titik kunci secara geostrategi serta secara ekonomi. Perairan Asia Tenggara merupakan kawasan sea lanes of communication (SLOCs) yang aktif dalam kegiatan ekonomi global, yang sekiranya mulai dari kegiatan ekspor impor internasional dari Asia menuju Eropa serta sekiranya 80 hingga 90 persen dalam perdagangan energi kawasan Timur Tengah munuju Asia melalui perairan tersebut. Sehingga, dapat dikatakan untuk negara - negara yang memiliki kepentingan di perairan tersebut memandang kawasan tersebut sebagai sebuah maritime chokepoint, seperti pada perairan Selat Malaka dan perairan Laut China Selatan, yang memiliki nilai strategis dalam menghubungkan kepentingan - kepentingan negara besar, baik secara ekonomi maupun secara politis.

Peningkatan pada isu perompakan dan perampokan bersenjata di kawasan Asia Tenggara didorong dengan kondisi ekonomi modern, politik dan perkembangan sosial di beberapa negara yang berhubungan di kawasan tersebut. Terlebih dengan kondisi perkembangan globalisasi, pengembangan dalam peningkatan ekonomi, dan sifat interdependensi yang membentuk kondisi dunia sekarang ini, dan hal tersebut termasuk dalam berkembangnya isu perompakan dan perampokan bersenjata. Peningkatannya dapat terlihat pada beberapa tahun ini, dimana perairan mengalami insiden perompakan dan perampokan bersenjata yang cukup aktif, yang terdata pada perkembangan dari tahun 2013 hingga tahun 2015, dimana peningkatan 12 percobaan perompakan hingga 104 percobaan perompakan di kawasan Selat Malaka (ReCAAP, 2015) dan perkembangan tersebut meningkat secara ekponensial.

Peningkatan pada insiden perompakan dan perampokan tersebut mendorong untuk terciptanya sebuah 
kerjasama untuk menanggulangi serta mencegah kondisi perompakan dan perampokan bersenjata dan meningkatkan keamanan, khususnya keamanan maritime. Dorongan tersebut kemudian menciptakan organisasi Regional Cooperation Agreement on Combating Piracy and Armed Robbery against Ships in Asia (ReCAAP) yang memiliki fokus terhadap perompakan dan perampokan bersenjata untuk melakukan peningkatan pada kondisi keamanan maritim di kawasan Asia.

Kehadiran ReCAAP memang memberikan kesempatan untuk mengurangi ancaman keamanan maritime, terkhusus pada isu perompakan dan perampokan bersenjata di kawasan Asia Tenggara dalam bentuk kerjasama. ReCAAP juga memiliki beberapa anggota ASEAN didalamnya, antara lain: Singapore, Phillipines, Thailand, Vietnam, Myanmar, Brunei, Laos dan Kamboja. Negara - negara tersebut sejatinya juga memiliki kepentingan dalam mengawasi keamanan maritim di perairan mereka masing - masing. Akan tetapi, ReCAAP belum dapat menarik dua negara yang memiliki kepentingan dan kunci vital dalam bidang keamanan maritime, yakni Indonesia dan Malaysia.

Dengan Indonesia dan Malaysia tidak bergabung dengan kiat kerjasama dengan ReCAAP, justru mudah saja mempertimbangkan optimalisasi ReCAAP dalam menjalin kerjasama untuk mencapai stabilitas keamanan maritime di kawasan Asia Tenggara. Terlebih dengan hadirnya kerjasama Indonesia, Singapura, Malaysia, dan Philippines dalam Malacca Strait Patrols dibeberapa kawasan perairan seperti Selat Malaka dan Laut Sulu (Southgate, 2015; Parameswaran, 2016) yang bisa saja menciptakan implikasi di kawasan Asia Tenggara, serta mempertanyakan eksistensi ReCAAP dalam menanggulangi keamanan di kawasan Asia Tenggara. Dengan demikian, tujuan dalam penulisan ini adalah memahami kinerja ReCAAP beserta kendalanya, serta mengidentifikasi implikasi yang diberikan ReCAAP terhadap kondisi keamanan maritime di kawasan Asia Tenggara. 
Awal Mula Munculnya Isu Keamanan Maritim di Kawasan Asia Tenggara

Pada akhir 1990-an, pembajakan kontemporer di Asia Tenggara mulai menarik perhatian yang lebih dan lebih internasional (Eklof, 2006). Semakin banyak serangan dan sifat serius dari beberapa insiden memicu kekhawatiran internasional tentang keamanan pengiriman internasional di perairan negara tersebut..

Tidak semua perairan di Asia Tenggara sama-sama terpengaruh oleh pembajakan, dan seiring waktu pembajakan, hotspot beralih ke wilayah perairan yang berbeda. Data pembajakan IMB yang disajikan pada Tabel 1 menunjukkan jumlah serangan yang dilaporkan secara komparatif di seluruh dunia, di Asia Tenggara dan di masing-masing negara Asia Tenggara. Namun saat mereka resmi, data ini perlu dipahami tidak komprehensif dan lengkap. Seperti yang diketahui IMB sendiri, hanya diperkirakan 50 persen serangan dilaporkan ke IMB saat itu, yang memungkinkan jumlah insiden yang tidak dilaporkan mungkin lebih tinggi lagi jika serangan terhadap kapal penangkap ikan juga diperhitungkan, karena serangan semacam itu terdata ke dalam statistik ini.

Insiden pada isu Peormpakan dan perampokan berssenjata antara tahun 1990 dan 1992, perairan antara Selat Malaka dan Singapura diidentifikasi sebagai rawan paling bajak laut di dunia. Setelah memulai patroli anti-pembajakan yang terkoordinasi di bidang ini, bagaimanapun, fokus pembajakan beralih ke Laut Cina Selatan, di mana sebagian besar serangan yang dilaporkan terjadi antara tahun 1993 dan 1995. Hal ini dapat dilihat pada Tabel 1 dibawah untuk memandang kondisi pada tahun 1994 dan 1995 dimana cukup marak terjadi tindakan tersebut.

Table 1 Lokasi Penyerangan Perompakan dan Perampokan Bersenjata di Asia tahun 1993 2006

\begin{tabular}{|c|c|c|c|c|c|c|c|c|c|c|c|c|c|}
\hline & '94 & '95 & '96 & '97 & '98 & '99 & '00 & '01 & '02 & '03 & '04 & 105 & '06 \\
\hline $\begin{array}{l}\text { South China } \\
\text { Sea }\end{array}$ & 6 & 3 & 2 & 6 & 5 & 3 & 9 & 4 & 0 & 2 & 8 & 6 & 1 \\
\hline HLH Area & 12 & 7 & 4 & 1 & 0 & 0 & 0 & 0 & 0 & 0 & 0 & 0 & 0 \\
\hline China/HK & 6 & 31 & 9 & 5 & 2 & 0 & 2 & 0 & 0 & 1 & 3 & 4 & 1 \\
\hline Macau & & & & & & & & & & & & & \\
\hline Indonesia & 22 & 33 & 57 & 47 & 60 & 115 & 119 & 91 & 103 & 121 & 93 & 79 & 50 \\
\hline Malaysia & 4 & 5 & 5 & 4 & 10 & 18 & 21 & 19 & 14 & 5 & 9 & 3 & 10 \\
\hline Thailand & 0 & 4 & 16 & 17 & 2 & 5 & 8 & 8 & 5 & 2 & 4 & 1 & 1 \\
\hline Philippines & 5 & 24 & 39 & 16 & 15 & 6 & 9 & 8 & 10 & 12 & 4 & 0 & 6 \\
\hline Vietnam & 2 & 4 & 0 & 4 & 0 & 2 & 6 & 8 & 12 & 15 & 4 & 10 & 3 \\
\hline $\begin{array}{l}\text { Malacca } \\
\text { Straits }\end{array}$ & 3 & 2 & 3 & 0 & 1 & 2 & 75 & 17 & 16 & 28 & 37 & 12 & 11 \\
\hline $\begin{array}{l}\text { Singapore } \\
\text { Straits }\end{array}$ & 3 & 2 & 2 & 5 & 1 & 14 & 5 & 7 & 5 & 2 & 8 & 7 & 5 \\
\hline Total & 63 & 115 & 137 & 105 & 96 & 165 & 254 & 162 & 165 & 188 & 170 & 122 & 88 \\
\hline Worldwide & 90 & 188 & 228 & 247 & 202 & 300 & 469 & 335 & 370 & 445 & 329 & 276 & 239 \\
\hline
\end{tabular}


Sekitar pertengahan 1990an, jumlah serangan yang lebih tinggi dilaporkan terjadi di Philipina (24 pada tahun 1995 dan 39 pada tahun 1996) dan di Thailand (16 pada tahun 1996 dan 17 pada tahun 1997), namun insiden ini dibayangi oleh munculnya beberapa serangan yang dilaporkan di Indonesia. Sebagian besar insiden yang dilaporkan terjadi di Indonesia adalah pencurian kecil, sering dilakukan di pelabuhan. Namun, peningkatan serangan yang dilaporkan di Selat Malaka menarik lebih banyak perhatian internasional setelah melonjak dari dua serangan aktual dan

\section{Dinamika Keamanan Internasional}

\section{Pasca 11 September}

Kondisi keamanan global saat ini merupakan hal yang kompleks, dimana tidak hanya aktor negara yang memeiliki peranan khusus dalam menangani isu keamanan, tetapi juga munculnya aktor non-negara yang menjadi spotlight dalam isu keamanan, yang menciptakan tren yang hingga saat ini menjadi pembahasan setiap negara, dikarenakan adanya perubahan yang signifikan pasca penyerangan terorisme 11 September 2001 (9/11). percobaan yang dilaporkan pada tahun 1999 sampai 75 pada tahun berikutnya (Tabel 1). Serangan di daerah ini menyebabkan kekhawatiran karena strategisnya selat tersebut sebagai salah satu jalur air tersibuk di dunia.

Adanya spekulasi bahwa orang-orang yang diidentifikasi sebagai teroris mungkin telah berkolusi dengan bajak laut di Selat Malaka dan tuduhan bahwa Gerakan Aceh Merdeka (GAM) atau anggota yang tidak bertanggung jawab atas beberapa serangan dengan menambahkan nada konspiratif (Liss \& Biggs, 2016) Penyerangan tersebut memiliki efek yang cukup detrimental, yang menyebabkan kondisi keamanan global menjadi lebih keruh dari sebelumnya. Hal ini juga menjadi sebuah motivasi keamanan tersendiri dari negara adidaya seperti Amerika Serikat, sebagai korban utama pada insiden transnasional tersebut, yang bahkan mendorong terciptanya global war on terrorism terhadap negara negara yang memiliki indikasi tersangka utama dalam insiden tersebut, dan menciptakan instabilitas di berbagai kawasan dikarenakan agresi militer yang bertubi - tubi. 
Global war on terrorism memang memberikan kerberhasilan yang parsial, dimana kondisi tersebut mengangkat kembali isu isu keamanan non-tradisional, seperti permasalahan terorisme, isu kejahatan transnasional, serta kehadiran Weapon of Mass Destruction sebagai sebuah pembahasan yang marak di berbagai kawasan. (Buzan, 2006)

Implikasi insiden 9/11 juga meliputi keprihatinan terhadap kondisi keamanan di berbagai kawasan. Bagi kawasan Eropa, Keutamaan AS membawa perubahan besar dalam hubungan mereka dengan Amerika dan dengan satu sama lain.. Terlebih, masih adanya kepentingan AS dalam NATO serta mengharapkan peranna yang lebih aktif untuk membantu penanganan pada global war on terrorism ini. (Gartner \& Cuthbertson, 2005, p. 116)

Sedangkan, bagi kawasan Asia-Pasifik pada umumya, dan kawasan Asia Tenggara khususnya, perubahan dalam agenda dan karakteristik kebijakan luar negeri AS telah melahirkan sebuah kompleks keamanan (security complex) yang semakin rumit. Meskipun menguatnya ancaman terorisme itu juga memiliki akar regional implikasi dari perang global melawan terorisme yang dimotori AS telah memperumit polapola hubungan antar negara kawasan, khususnya di antara negara-negara ASEAN.

Dengan kata lain, perkembangan situasi keamanan di Asia-Pasifik pada umumnya, dan di kawasan Asia Tenggara pada khususnya, tidak menunjukkan gambaran masa depan menggembirakan. Setidaknya ada beberapa faktor dalam memandang perkembangan keamanan tradisional pasca 9/11 di kawasan Asia Pasifik, yakni:

1. Kawasan Asia Pasifik ini masih diwarnai oleh sejumlah sengketa wilayah dan perbatasan. Sengketa wilayah dan perbatasan ini, apabila tidak diselesaikan dengan baik, dapat menjadi isu keamanan yang serius bagi kawasan.

2. Masih adanya kecurigaan dan ketegangan bilateral di antara negara negara di kawasan. Fakta bahwa meskipun negara-negara tersebut telah tergabung dalam ASEAN, namun belum dapat menyelesaikan persoalan yang ada, menunjukkan bahwa masalah ini tidak dapat diabaikan begitu saja. 
3. Kawasan Asia Timur dan ancaman nuklir Korea Utara. Beberapa insiden peluncuran hulu ledak ke beberapa negara tetangga, menunjukkan bahwa masalah Korea Utara ini merupakan masalah serius bagi keamanan tidak hanya bagi kawasan Asia Timur Laut, tetapi juga bagi kawasan Asia Tenggara. Kompleksitas pada pecahnya konflik terbuka di kawasan ini, akan membawa dampak ekonomi dan keamanan yang tidak kecil bagi kawasan Asia Tenggara. (Sukma, 2003)

Disamping ketiga masalah keamanan tradisional di atas, kawasan Asia-Pasifik, khususnya di subkawasan Asia Tenggara, merupakan kawasan yang sarat dengan sejumlah permasalahan dan ancaman nontradisional. Disamping menghadapi masalah terorisme, negara-negara di kawasan sudah lama berkutat menghadapi masalah penyelundupan senjata ringan, separatisme bersenjata, penjualan wanita dan anak-anak, pemalsuan dokumen dan surat-surat berharga, bajak laut, kebakaran hutan, imigran legal, pencucian dan pemalsuan uang, serta perdagangan narkotika dan obat-obat terlarang. Peningkatan pada isu non-tradiisonal juga sudah dilakukan pada tingkat regional ASEAN, tetapi tidak mendapatkan hasil yang signifikan. (Sukma, 2003)

$$
\text { Perkembangan terhadap }
$$

kondisi setelah 9/11, isu pembajakan dan terorisme sering kali digabungkan. Adanya keprihatinannya bahwa teroris dapat bergabung dengan gerombolan bajak laut untuk melakukan kekejaman di perairan Asia Tenggara, terutama di Selat Malaka yang strategis, dikarenakan sekitar sepertiga dari perdagangan dunia dan satu setengah dari pasokan energi global melwati selat tersebut. Dua skenario yang paling sering dikutip termasuk teroris yang menenggelamkan satu atau lebih kapal besar dalam upaya untuk memblokir Selat dan melumpuhkan ekonomi dunia, dan militan menggunakan kapal tanker minyak mentah atau gas alam sebagai "bom terapung" di sebuah pelabuhan besar di Asia.

\section{Kehadiran ReCAAP Sebagai} Lembaga Dalam Bidang Keamanan Maritim

Kondisi keamanan maritime yang senantiasa berubah - ubah mendorong terciptanya Regional Cooperation Agreement on Combatting Piracy and Armed 
Robbery in Asia (ReCAAP) yang merupakan organisasi yang berlandaskan pada kinerja antara pemerintah dengan pemerintah (government-to-government) yang melakukan promosi terhadap peningkatan kerjasama antara patroli laut yang tergabung dengan perjanjian ReCAAP untuk melawan pembajakan dan perampokan bersenjata di kawasan laut Asia, yang memiliki peran yang cukup vital terhadap kehidupan perekonomian kawasan.

Konsep pengembangan kerjasama regional tersebut, disarankan oleh mantan Perdana Menteri Jepang, Junichiro Koizumi, pada pertemuan ASEAN+3 pada bulan November 2001, yang pada titik ini menjadi acuan dasar dalam terciptanya perintisan ReCAAP. Hal ini mendorong untuk terciptanya perjanjian dalam menanggulangi isu tersebut, yang dirumuskan pada tahun 2002 oleh ASEAN+3, dan difinalisasi di Tokyo, Jepang, pada tanggal 11 November 2004 dengan ASEAN+6, serta mulai berlaku pada tanggal 4 September 2006. Kemudian, pada tanggal 29 November 2006, terbentuklah ReCAAP sebagai sebuah organisasi pertama yang melakukan kerjasama antar pemerintah pertama, dalam bidang menanggulagi isu perompakan di kawasan Asia, dan bertempat di Singapura yang diakui sebagai salah satu organisasi internasional, yang pertama kali terdiri dari 14 Contracting Parties, yakni: Jepang, Cina, Korea Selatan, India, Sri Lanka, Bangladesh, Singapura, Thailand, Filipina, Brunei Darussalam, Laos, Myanmar, Vietnam, Kamboja. (ReCAAP, 2016, p. 33)

ReCAAP bertujuan untuk memberantas isu piracy dan armed robbery yang terjadi di wilayah Asia dan sebagai pusat informasi tentang aksi pembajakan dan perampokan bersenjata diatas kapal kepada kapal kapal patroli laut yang difasilitasi oleh negara - negara anggotanya dan alih teknologi kepada negara lain yang membutuhkan dengan beracuan pada tiga pilar dasar, yaitu:

1. Berbagi informasi antara negara-negara anggota ReCAAP.

2. Peningkatan kapasitas antara negara-negara anggota dengan berbagi praktik terbaik dalam memerangi pembajakan dan perampokan bersenjata.

3. Melakukan perjanjian kerjasama dengan seperti- organisasi berpikiran untuk memperkuat 
kemampuan negara-negara anggota untuk mengelola insiden di laut. (ReCAAP, 2006)

$$
\text { Sehingga, }
$$

dalam

perkembangannya, ReCAAP dengan asas kebebasan navigasi laut, memiliki kemampuan untuk melakukan pembagian informasi perihal perompakan serta perampokan bersenjata diatas kapal, terlebih pembagian kompilasi data biasa yang dilakukan secara bulanan, menjadikan ReCAAP mampu melakukan pemberian informasi secara real-time. ReCAAP juga memiliki kemampuan dalam menciptakan keamanan maritime yang bersifat cepat tanggap, hal ini sebagaimana tujuan utama ReCAAP sebagai organisasi yang memberikan informasi real time secara jelas terhadap negara - negara anggotanya.

\section{Kinerja ReCAAP dalam}

\section{Menanggulangi Isu Keamanan}

\section{Maritim di Kawasan Asia Tenggara}

Upaya dalam menghadapi isu perompakan dan perampokan oleh ReCAAP dapat dipantau melalui laporan tahunan yang diterbitkan oleh ReCAAP dalam tugasnya untuk memantau serta membagikan informasi tersebut secara Real Time. Dikarenakan, menurut ReCAAP, kepentingan pembagian informasi mulai dari pihak negara maupun dari pihak pemilik kapal atau dapat dikatakan pihak ketiga menjadi vital, untuk memahami dimana saja titik titik penyerangan dan dapat diidentifikasi sebagai sebuah titik panas atau hotspot, dari tahun - ke tahun untuk mendapatkan penanggulangan yang utuh serta menciptakan keamanan tersendiri di jalut laut tersebut. Adanya potensi ReCAAP untuk menjadi sebuah komunitas keamanan yang bersifat komprehensif yang dapat dilihat perjanjiannya yang mengikat negara negara anggotanya serta bantuan infrastruktur yang cukup untuk menjadi komunitas keamanan di kawasan Asia.

ReCAAP juga melakukan penciptaan terhadap kategorisasi yang mampu menciptakan pemetaan terhadap titik - titik panas yang berada di kawasan Asia Tenggara yang memiliki kelemahan terhadap penyerangan di perairan tertentu serta Kategorisasi ini juga menjadi alat bantu untuk mengurangi perompakan yang mampu menyatakan bahwa setidaknya adanya penurunan pada tindakan perompakan di kawasan Laut China Selatan, yaitu pada tahun 2010, 
terjadi setidaknya 25 insiden perompakan menjadi 18 pada tahun 2011, serta, adanya peningkatan pada insiden tersebut di kawasan Selat Malaka, yang pada tahun 2010, hanya 8 insiden yang teridentifikasi, menjadi 26 pada tahun 2011.

Dalam peningkatan keamanan, ReCAAP menyarankan untuk meningkatkan kehati-hatian, pada saat malam hari, yang dimana kegiatan tersebut terjadi pada malam hari, adapun jika terjadi pada siang hari, diperlukan pengawasan khusus serta melakukan laporan berkala kepada negara terdekat di perairan tersebut (ReCAAP, 2012). Selain itu, perlunya perluasan pada wilayah cakupan patroli atau pemindahan titik patrol untuk mengurangi kegiatan perompakan dan perampokan bersenjata tersebut, serta peningkatan laporan antar Focal Point untuk melakukan tinjauan awal pada lokasi kejadian (ReCAAP, 2011, p. 38).
Table 2 Tindakan Perompakan di Kawasan Asia Tenggara tahun 2006 - 2014

\begin{tabular}{|c|c|c|c|c|c|c|c|c|c|c|}
\hline Location & 2006 & 2007 & 2008 & 2009 & 2010 & 2011 & 2012 & 2013 & 2014 & Total \\
\hline Vietnam & 3 & 5 & 12 & 8 & 13 & 8 & 4 & 9 & 6 & 68 \\
\hline Indonesia & 49 & 40 & 23 & 20 & 47 & 49 & 72 & 90 & 46 & 436 \\
\hline $\begin{array}{l}\text { Malacca and } \\
\text { Singapore } \\
\text { Straits }\end{array}$ & 13 & 7 & 10 & 8 & 8 & 26 & 15 & 12 & 48 & 147 \\
\hline Malaysia & 11 & 8 & 13 & 15 & 18 & 17 & 11 & 6 & 5 & 104 \\
\hline Philippines & 5 & 6 & 8 & 5 & 5 & 6 & 3 & 5 & 5 & 48 \\
\hline Singapore & 0 & 0 & 0 & 0 & 2 & 3 & 2 & 0 & 0 & 7 \\
\hline Thailand & 1 & 1 & 0 & 2 & 1 & 0 & 0 & 0 & 0 & 5 \\
\hline Myanmar & 0 & 0 & 0 & 1 & 0 & 1 & 0 & 1 & 0 & 3 \\
\hline $\begin{array}{l}\text { South China } \\
\text { Sea }\end{array}$ & 3 & 6 & 7 & 13 & 25 & 18 & 1 & 11 & 42 & 132 \\
\hline China & 1 & 0 & 0 & 1 & 1 & 1 & 1 & 0 & 0 & 5 \\
\hline TOTAL & 86 & 73 & 73 & 73 & 120 & 129 & 115 & 134 & 152 & 955 \\
\hline
\end{tabular}

Sumber: Annual Report ReCAAP 2006 - 2014

Tabel 2 diatas mengidentifikasi tahun 2013, memiliki peningkatan paling tinggi secara insiden perompakan dan perampokan bersenjata. Tercatat setidaknya ada 150 insiden, serta terciptanya tren baru dikalangan perompak, yakni melakukan pencurian minyak illegal atau illegal siphoning serta penyerangan terhadap kapal yang berlabuh (ReCAAP, 2013). Kinerja ReCAAP juga mendata adanya penurunan insiden pada kapal kapal yang berlayar melewati laut China Selatan secara besar, dikarenakan memiliki kemungkinan untuk adanya perubahan wilayah operasi di kawasan tersebut, yang berbanding terbalik dengan Selat Malaka / Selat Singapura 
yang menjadi kawasan yang aktif selama tahun 2013, an memilki peningkatan yang cukup tinggi. Sehingga diperlukan pengawasan lebih lanjut pada isu yang terjadi di Selat Malaka / Selat Singapura.

Seiring berjalannya waktu, ReCAAP pada tahun 2014 memberikan indikasi pada kemunculan tren, illegal siphoning oleh kelompok perompak ataupun perampokan bersenjata berjalan secara sporadic dan lebih aktif, terjadi peningkatan dikarenakan mudahnya akses kepada kapal kapal tanker. Perpindahan tren juga terjadi, yang dimana tahun tahun sebelumnya perompakan maupun perampokan bersenjata lebih banyak dialami oleh kapal kapal yang bersandar, menjadi kapal kapal yang sementara berjalan menuju pelabuhan terdekat atau destinasinya, hal ini disebabkan oleh kurangnya tingkat kewaspadaan dan keamanan terhadap kapal - kapal tersebut (ReCAAP, 2014).

Kemunculan

ReCAAP

memang memberikan harapan pada kondisi keamanan maritime yang menciptakan kemungkinan terhadap penangkapan ataupun melakukan interaksi aktif yang mampu memperkecil tindakan perompakan serta perampokan tersebut terjadi Pemberian informasi secara real time juga memungkinkan untuk melakukan respon cepat untuk meringkus oknum - oknum tersebut, sehingga mengurangi kerusakan yang akan terjadi.

Keterbatasan

pengaruh ReCAAP sangatlah disayangkan, karena kondisi ReCAAP yang mampu memberikan informasi secara cepat dan real time, terkendala pada kemampuan ReCAAP untuk melakukan penindakan serta penegakan hukum di kawasan. ReCAAP tidak memiliki wewenang serta otoritas untuk mendorong patrol laut yang dimiliki oleh negara negara anggota untuk melakukan pengamanan secara cepat, dikarenakan kemampuan ReCAAP hanya sebatas membantu penyaluran informasi serta memberikan bantuan analisis yang bersifat epistemic untuk mencegah serta meningkatkan kemampuan pihak - pihak berwenang dalam menangani permasalahan sehingga mengurangi keefektifan pada kemampuan penanganan perompakan dan perampokan bersenjata yang dilakukan pada kapal yang sedang berlayar maupun yang tengah 
bersandar, yang menciptakan kelemahan tersendiri pada ReCAAP.

Kurangnya ruang gerak yang dimiliki ReCAAP juga berpedoman pada perjanjian yang telah ditandatangani oleh pihak - pihak focal point yang memang bertujuan untuk mengurangi ruang lingkup apa saja yang dilakukan oleh ReCAAP sehingga dapat dipantau oleh negara negara tersebut, dikarenakan dalam perjanjian tersebut ReCAAP tidak memiliki kewajiban untuk melakukan tindakan yang lebih spesifik kecuali dalam berbagi informasi dalam sebuah insiden penyerangan maupun pembajakan. (Liss, 2017, p. 6)

Penegakan hukum juga menjadi kendala untuk menciptakan efek deterens dari ReCAAP sendiri, yang hanya berfokus pada pembagian informasi serta memberikan peningkatan pada capacity building. Terlebih, adanya faktor yang tidak dapat dilangkahi oleh ReCAAP, yaitu kedaulatan negara negara, terlebih di kawasan Asia Tenggara, yang mempercayai dalam kebijakan luar negerinya yaitu konsep kedaulatan, yang bahkan menjadi isu sensitive dalam lingkup regional Asia Tenggara sekalipun.
Dalam upaya penegakan hukum kepada oknum perompakan dan perampokan bersenjata, kemampuan tersebut diserahkan kepada masing - masing anggota ReCAAP, sebagaimana tertulis didalam perjanjian ReCAAP, negara negara yang menjadi Contracting Party maupun Focal Point, adalah yang memiliki wewenang untuk menegakan hukum jika oknum perompakan dan perampokan bersenjata ditangkap di perairan negara tersebut.

Dengan kata lain, ReCAAP tidak memiliki kemampuan untuk melakukan turun tangan dengan situasi yang dihadapi di kawasan Asia Tenggara, dikarenakan kesepakatan dalam memahami tidak boleh adanya intervensi dari negara lain. Sehingga, penegakan hukum kembali kepada hukum nasional yang berlaku di negara tersebut dalam menyelesaikan kejahatan berupa perompakan dan perampokan bersenjata diatas kapal. 
Implikasi pada Kehadiran ReCAAP dalam Mendorong Kerjasama Keamanan Maritim

Implikasi yang dimiliki oleh ReCAAP dapat dilihat pada ranah, yaitu tantangan kepada prinsip prinsip yang berlaku di kawasan regional Asai Tenggara serta dampaknya yang bersifat politis maupun strategis dalam mengurangi nagka tindakan perompakan dan perampokan di kawasan.

Tantangan pada prinsip prinsip yang berlaku di kawasan, seperti prinsip ASEAN yang tidak memperbolehkan negara - negara anggotanya melakukan intervensi memberikan pukulan mundur pada ReCAAP dalam menanggulangi isu keamanan maritime di perairan tersebut. Prinsip ASEAN pada dasarnya bukan sebuah mekanisme pemecahan masalah, akan tetapi, merupakan mekanisme penghindaran konflik. Penerapan cara ASEAN memiliki dua tujuan strategis. Pertama adalah tidak membiarkan perselisihan bilateral antara negara-negara ASEAN mengganggu stabilitas regional yang lebih luas dan berfungsinya ASEAN itu sendiri. Kedua adalah tidak membiarkan isu bilateral antara negara-negara ASEAN dan non-
ASEAN secara negatif mempengaruhi hubungan intra-ASEAN (Weatherbee, 2010, p. 128).

Adanya sensitivitas kedaulatan secara tradisional sangat tinggi di antara negara-negara Asia Tenggara, dan mereka memainkan peran yang menentukan dalam formulasi kebijakan luar negeri di negara-negara ini. Kepekaan ini telah membuat prinsip nonintervensi landasan hubungan negara intraregional; Mereka tidak diragukan lagi merupakan penghambat kerjasama maritim di Asia Tenggara. (Bradford, 2005, p. 73)

Cara pandang ASEAN mengurangi potensi kinerja ReCAAP, terlebih tidak mampu menunjukan potensinya dalam mereduksi angka kejahatan perampokan bersenjata dan perompakan di perairan Asia Tenggara. Situasi ini menyulitkan ReCAAP untuk melakukan aksi cepat tanggap dengan memberikan informasi terkait dengan patrol laut sekitar, dikarenakan permasalahan perbatasan masih menjadi isu sensitive dalam melakukan tindakan patroli.

Prinsip sekuritisasi yang dimiliki oleh negara - negara besar seperti Amerika Serikat dan Jepang tentu memiliki tantangan tersendiri 
kepada ReCAAP. Terlebih, adanya kepentingan negara - negara tersebut dalam isu - isu keamanan serta kaitannya dengan ekonomi dan nilai strategis lainnya, di kawasan perairan Asia Tenggara. Ancaman terhadap insiden terorisme maritim di Asia Tenggara mungkin telah dilebihlebihkan, tapi ini adalah ancaman yang tidak dapat dikesampingkan, dan satu di antara banyak negara, terutama Amerika Serikat, menganggapnya sangat serius.

Dalam kesaksian di hadapan Kongres AS pada tanggal 31 Maret 2004, Admiral Thomas Fargo, Komandan komando tempur terbesar militer AS, Komando Pasifik (PACOM) yang berbasis di Honolulu, Hawaii, meluncurkan sebuah program baru yang disebut Inisiatif Keamanan Maritim Regional (RMSI) yang dirancang untuk meningkatkan kerja sama antara Amerika Serikat dan negara-negara Asia Tenggara untuk mengatasi ancaman keamanan transnasional di laut termasuk terorisme, pembajakan, proliferasi senjata pemusnah massal dan perdagangan ilegal (Storey, 2009, p. 40).

Meskipun adanya niatan baik dari Amerika Serikat untuk menangani isu keamanan maritime, tetapi Malaysia dan Indonesia merasa terganggu dengan laporan tersebut, serta mengecam usulan tersebut sebagai pelanggaran terhadap kedaulatan mereka dan memperingatkan bahwa kehadiran pasukan A.S. di Selat Malaka hanya akan memicu radikalisme Islam di Asia Tenggara. Belum lagi, Amerika Serikat yang tidak meratifikasi UNCLOS, menjadikannya lebih leluasa keluar masuk di kawasan Selat Malaka, yang jika menemukan oknum perompakan ataupun perampokan bersenjata dapat melakukan pengejaran hingga memasuki batas wilayah negara tersebut.

Sekuritisasi ini juga menjadi tantangan kepada ReCAAP, dikarenakan tindakan yang dilakukan oleh Amerika Serikat juga berdampak kembali kepada ReCAAP, yaitu tidak bergabungnya Indonesia dan Malaysia, yang merupakan salah satu aktor vital dalam isu keamanan maritime terkhusus dalam perompakan dan perampokan bersenjata, ke dalam ReCAAP

Selain Amerika Serikat sebagai sebuah negara yang berusaha melakukan sekuritisasi untuk mereduksi kondisi keamanan maritim 
di kawasan, Jepang juga hadir sebagai salah satu yang melakukan inisiatif untuk menciptakan konsep kerjasama dalam mengurangi ancaman perompakan dan perampokan di kawasan Asia Tenggara. Inisiatif ini didorong dengan motif ekonomi yang dimiliki Jepang di perairan tersebut, serta kehadiran Jepang yang memiliki sejarah pada partisipasi aktif dalam menangani isu keamanan maritime secara global. (Johnson \& Valencia, 2005, pp. 131-132)

Jepang merupakan salah satu mitra aktif ASEAN serta pihak penemu ReCAAP di kawasan Asia, untuk memperkuat keamanan laut terhadap isu perompakan dan perampokan yang memungkin untuk merugikan berbagi pihak yang melakukan perdagangan melalui laut. Bantuan yang berupa inisiatif, Obuchi Initiative, yang didalamnya terdiri dari saran untuk menciptakan dorongan terhadap terciptanya mekanisme joint patrol di kawasan yang terdiri dari patrol laut yang dimiliki negara negara lain, penciptaan pembagian informasi yang konkrit dan terpadu, dan bantuan dana untuk merealisasikan hal tersebut. (Johnson \& Valencia, 2005, p. 135). Sedangkan, negara negara seperti Indonesia dan
Malaysia, yang merupakan aktor penting serta mitra yang tepat untuk bergabung dengan ReCAAP, tidak menandatangani perjanjian tersebut, dikarenakan cakupan dalam perjanjian tersebut yang melingkupi permasalahan pada laut teritorial. (Sato, 2007)

Intervensi yang dilakukan inilah, menjadi sebuah "komitmen" negara - negara besar yang memiliki kepentingan di kawasan Asia Tenggara, khususnya di perairan Selat Malaka, karena kepentingan ekonomis serta strategis, sehingga diperlukan pengawasan lebih lanjut, dan memerlukan untuk negara - negara tersebut untuk turun tangan.

Tantangan yang diberikan oleh kondisi prinsip - prinsip yang berlaku di kawasan, tentu memberikan dampak terhadap ReCAAP yakni, secara politis dan secara strategis, terutama dalam mendorong kerjasama di kawasan Asia Tenggara. Secara politis, negara - negara yang tidak bergabung pada kerjasama yang ditawarkan ReCAAP seperti Malaysia dan Indonesia, yang merupakan aktor vital dalam menangani isu keamanan maritime, khususnya pada isu perompakan dan perampokan menjadi 
implikasi yang signifikan pada kehadiran ReCAAP di kawasan.

Kondisi tersebut dikarenakan Malaysia merasa terganggu dengan penempatan ReCAAP di Singapura, terlebih di Malaysia sendiri juga ditempati oleh lembaga maritim yaitu International Maritime Bureau (IMB). Selain terganggu dengan penempatan ReCAAP, Malaysia juga memiliki kekhawatiran untuk adanya persaingan antara dua instansi yang memiliki kemampuan yang hampir sama dalam membantu memberantas isu perompakan dan perampokan bersenjata di kawasan Asia Tenggara.

Sedangan untuk Indonesia, adanya halangan sensitif untuk bergabung dengan ReCAAP, padahal dalam tinjauan data setiap tahunnya, isu perompakan dan perampokan bersenjata memiliki potensi tinggi di perairan Indonesia. Tetapi, hal ini didasarkan pada alasan yang logis, yakni Indonesia percaya bahwa perompakan dan perampokan bersenjata yang terjadi dikarenakan oleh kemiskinan dan kesempatan ekonomi yang dimiliki oleh masyarakat pesisir. Oleh karenanya, Indonesia perlu menyelesaikan sendiri, tanpa perlu bergabung didalam ReCAAP dan menjaga hubungan baik demi kelancaran dan keharmonisan negara - negara di kawasan Asia Tenggara. Terutama menjalin kerjasama dengan organisasi - organisasi terkait seperti ReCAAP dikarenakan adanya kesempatan untuk memperkuat kemampuan keamanan maritime, khususnya dalam bidang kemampuan pencegahan tindakan perompakan dan perampokan.

Implikasi kinerja dari ReCAAP juga berpengaruh terhadap bagaimana perompakan dan perampokan itu terjadi, terlebih ketika aksi perompakan dan perampokan bersenjata tersebut dilakukan pada kawasan yang memiliki jurisdiksi ekslusif dari negara - negara litoral tersebut yang dapat menimbulkan permasalahan sensitive seperti kedaulatan negara tersebut.

Malaysia dan Indonesia tentu menjadi sebuah dampak politik yang diberikan oleh ReCAAP, tetapi disini juga kita dapat melihat bagaiaman ReCAAP sebagai sebuah organisasi kerjasama multilateral menjadi sebuah medium dalam menciptakan jembatan untuk Indonesia dan Malaysia turut berperan serta secara aktif dalam menanggapi isu - isu keamanan Maritim di kawasan Asia Tenggara. 
Dalam penanganan strategis, ReCAAP tentu meningkatkan kemampuan negara - negara focal point yang menjadi anggotanya dalam menangani isu keamanan maritime di kawasan, dikarenakan ReCAAP senantiasa melakukan pelatihan serta seminar yang diikuti oleh negara negara focal point, khususnya negara negara di Asia Tenggara.

Bantuan penyebaran informasi serta kemampuan yang bersifat epistemik yang di miliki ReCAAP menjadi salah satu kelebihan strategisnya. Kelompok epistemic ini kemudian melakukan analisis terpadu dalam memahami tren yang saat ini sedang berlaku pada oknum perompakan dan perampokan bersenjata, serta memahami kebutuhan negara - negara dalam upaya meningkatkan kemampuannya dalam menangani isu perompakan dan perampokan bersenjata tersebut. Seperti yang diketahui, sebelum mengenal musuh yang dihadapi, kita harus mengetahui tentang diri sendiri, serta memahami bahwa informasi merupakan sumber kekuatan pertama untuk menanggulangi isu apapun itu. Pemberian informasi secara real time menjadikan kemampuan stratesgis angkatan laut maupun para penjaga pantai lebih cepat dan tepat untuk menyelamatkan kapal - kapal yang menjadi target dari oknum perompakan atau perampokan bersenjata di perairan negara masing masing. Sehingga, negara tersebut mampu melakukan respon cepat terhadap kapal yang membutuhkan bantuan.

Nilai strategis kehadiran ReCAAP di kawasan juga dapat dipandang sebagai sebuah mekanisme kerjasama multilateral yang komprehensif dalam bidang keamanan laut, yang mencoba untuk mengurangi angka perompakan dan perampokan bersenjata di perairan sekitar dalam memahami kinerjanya.

\section{Kesimpulan}

Peran ReCAAP di kawasan Asia Tenggara berpengaruh terhadap kondisi keamanan maritime, karena adanya pendataan yang lebih spesifik, pemberian informasi secara real time, dan bantuan terhadap peningkatan mutu negara - negara anggotanya menjadi kunci dalam peranan ReCAAP di kawasan Asia Tenggara. Selain itu kendala yang dihadapi oleh ReCAAP terfokus kepada instrument operasional seperti penindakan dan penegakan hukum, yang masih 
menjadi kekurangan ReCAAP untuk mencapai potensinya dalam menangani isu perompakan dan perampokan bersenjata di kawasan Asia, khususnya di kawasan Asia Tenggara.

Implikasi pada kehadiran ReCAAP juga mendorong mekanisme kerjasama dalam bidang keamanan maritime, kepada negara - negara anggotanya di Asia Tenggara. Halangan kepada prinsip - prinsip yang berlaku seperti prinsip ASEAN serta sekuritisasi oleh negara - negara besar memberikan efek terhadap kinerja serta implikasi kehadirannya di kawasan Asia Tenggara. Dampak yang diberikan secara politis yang membawa isu kedaulatan masih menjadi kekhawatiran tersendiri pada implikasi ReCAAP untuk melakukan penanggulangan isu perompakan dan perampokan di kawasan Asia Tenggara. Secara strategis, ReCAAP memberikan kemampuan pada penanganan keamanan maritime di kawasan Asia Tenggara, mekanisme ini juga memiliki sistem yang terstruktur dalam menjalankan kinerjanya kedepan. Solusi dalam menanggapi kondisi ReCAAP terlihat memerlukan reformasi dalam perjanjian ReCAAP maupun dalam sistematika jalannya ReCAAP yang lebih solid, serta ReCAAP dapat menjadi sebuah badan koordinasi, dalam melakukan kegiatan Coordinated Patrol, yang menciptakan keleluasaan tanpa adanya gangguan terhadap perbatasan yang masih menjadi hal yang cukup kental oleh ASEAN sekarang ini.

\section{DAFTAR PUSTAKA}

Bradford, J. F. (2005). Naval War College Review. The Growing Prospects for Maritime Security Cooperation in Southeast Asia, 58(3).

Buzan, B. (2006). Will the 'global war on terrorism' be the new Cold War? International Affairs , 82(6), 1101-1118.

Eklof, S. (2006). Pirates in Paradise: A Modern History of Southeast Asia's Maritime Marauders. Copenhagen: NIAS Press.

Gartner, H., \& Cuthbertson, I. M. (2005). European Security and Transatlantic Relations after 9/11 and the Iraq War. New York: Palgrave.

Johnson, D., \& Valencia, M. (2005). Piracy in Southeast Asia: Status, Issues, and Responses. Singapore: ISEAS Publication.

Liss, C. (2017). Piracy in Southeast Asia: Trends, Hotspots and Responses (1 ed.). New York, New York, United States: Routledge.

Liss, C., \& Biggs, T. (2016). Piracy in Southeast Asia: Trends, 
Hotspots, and Responses. New York: Routledge.

ReCAAP. (2006). About ReCAAP. Retrieved December 21, 2016, from ReCAAP.org: http://www.recaap.org/AboutR eCAAPISC.aspx

ReCAAP. (2011). Annual Report 2011. Annual Report, ReCAAP, Singapore.

ReCAAP. (2012). Annual Report 2012. Annual Report, ReCAAP.

ReCAAP. (2013). Annual Report 2013. Annual Report, ReCAAP, Singapore.

ReCAAP. (2014). Annual Report 2014. Annual Report, ReCAAP, Singapore.

ReCAAP. (2015). Annual Report 2015. ReCAAP. Singapore: ReCAAP.

ReCAAP. (2016). Commemorating a Decade of Cooperation. Regional Cooperation Agreement on Combating
Piracy and Armed Robbery against Ships in Asia. ReCAAP.

Storey, I. (2009). Maritime Security in Southeast Asia: Two Cheers for Regional Cooperation. Southeast Asian Affairs, 2009.

Sukma, R. (2003). Keamanan Internasional Pasca 11 September: $\quad$ Terorisme, Hegemoni As Dan Implikasi Regional. Seminar Pembangunan Hukum Nasional Viii Tema Penegakan Hukum Dalam Era Pembangunan Berkelanjutan. Denpasar: Badan Pembinan Hukum Nasional Departemen Kehakiman Dan Hak Asasi Manusia Ri.

Weatherbee, D. E. (2010). International Relations in Southeast Asia: The Struggle for Autonomy (2nd Edition ed.). Pasir Panjang, Singapore, Singapore: ISEAS Publishing. 